\title{
TWO NEW TAXA OF PARHOLASPIDAE EVANS, 1956 (ACARI, MESOSTIGMATA) FROM TENERIFE (CANARY ISLANDS)
}

\author{
M. L. Moraza* and M. A. Peña**
}

\begin{abstract}
Two new taxa of the family Parholaspidae Evans, 1965 -Holaspina canariensis $\mathbf{n}$. sp. and Gamasholaspis gamasoides canariensis n. subsp.- - are described on the basis of specimens collected in Tenerife (Canary Islands). Idiosomal chaetotaxy, poroidotaxy and adenotaxy of these two species are illustrated and the chaetotaxy of the caudal body region is discussed.

Key words: Acari, Mesostigmata, Parholaspidae, Holaspina canariensis sp. nov., Gamasholaspis gamasoides canariensis subsp. nov., taxonomy, Tenerife (Canary Islands).
\end{abstract}

\section{RESUMEN}

Dos nuevos taxa de Parholaspidae Evans, 1956 (Acari, Mesostigmata) en Tenerife (islas Canarias)

Sobre ejemplares recolectados en Tenerife (Islas Canarias), se describen dos nuevas especies de la familia Parholaspidae Evans, 1965 - Holaspina canariensis sp. n. y Gamasholaspis gamasoides canariensis subsp. n.- - Se ilustra la quetotaxia, poroidotaxia y adenotaxia del idiosoma de las dos especies y se discute la quetotaxia de la región caudal del cuerpo.

Palabras clave: Acari, Mesostigmata, Parholaspidae, Holaspina canariensis sp. nov., Gamasholaspis gamasoides canariensis subsp. nov., taxonomía, Tenerife, Canarias.

\section{Introduction}

The family Parholaspidae Evans, 1956 is found in tropical, subtropical and temperate zones with wet clime (Paleartic, Indomalayan, Neotropical and Neartic regions). Except for the works of Krantz
(1960), Petrova (1967, 1970, 1977), Ishikawa (1978, 1980a, b), Datta \& Bhattacharjee (1989, 1991) and Lee \& Lee (2000), there are no extended publications of this family whose members are free living predaceous mites which live in litter, the surface layer of the soil, moss, in association with

* Departamento de Zoología y Ecología, Facultad de Ciencias, Universidad de Navarra, C/ Irunlarrea s/n, Pamplona 31080, (Navarra), Spain. E-mail: mlmoraza@unav.es

** Área del Medio Ambiente del Cabildo de Gran Canaria, C/ Prof. Agustín Millares Carló, s/n, 1º, 35003, Las Palmas de Gran Canaria, España. E-mail: estevez1@auna.com 
mammals Cricetidae, Muridae) (Gu \& Guo, 1996; Chen et al., 1994) and even in caves (Ishikawa, 1995, 2002).

The mesostigmatic fauna on the Canary Islands (307 kilometres off the west coast of Africa, at $28^{\circ}$ north latitude) and in the Macaronesian Region is poorly studied and only 42 species have been reported (Estrada-Peña \& Sánchez, 1988; Domingo-Quero et al., 2003; Ferragut \& Peña, 2003; Oromí \& Báez, 2001; Machado, 2002; Moraza \& Peña, 2005a, b; Moraza et al., 2005). Additional surveys conducted in natural ecosystems on some other islands in the Macaronesian Region will contribute to the knowledge of the taxonomy of mites in this unique geographical region.

\section{Material and methods}

Mites were extracted from samples using Berlese Tullgren funnels. Specimens were mounted individually in Hoyer's medium and sealed with Glyptal insulating varnish. Morphological observations, measurements (given in micrometers and made with stage-calibrated eyepiece micrometers) and illustrations were made using compound microscopes equipped with phase-contrast optical systems. Idiosomal setal notation follows Lindquist \& Evans (1965), with modifications for the caudal region as given by Lindquist (1994) and Lindquist \& Moraza (1999); leg chaetotaxy follows Evans (1963). Idiosomal notation of glands and lyrifissures follows Johnston \& Moraza (1991).

The ontogeny of dorsal and ventral idiosomal setae is based on descriptions of larva and protonymphal instars of Gamasholapis variabilis given by Petrova (1977), protonymph of Parholaspulus breguetovae given by $\mathrm{Ma}$ et al. (2001), deutonymph of Gamasholaspis browningi given by Petrova $(1967,1968)$ and deutonymph of Parholaspulus paradichaetes given by $\mathrm{Ma}$ et al. (2001). Several setae of the caudal body region bear two different notations: superior notation, referring to the notation widely used and recommended and smaller size notation, referring to the possible sixth elements of the opistonotal region discussed by Lindquist (1994).

In the discussions following descriptions of new species, the comparisons with previously described species are based solely on published descriptions.

\section{Holaspina canariensis sp. nov. (Figs. 1-11)}

Material STUdied. Holotype adult female (mounted, permanent slide), 25.I.1997, M.A. Peña leg., from soil and litter beneath Myrica faya Ait., altitude 950 m, UTM coordinates: 28RCS 748565 (T-44). Paratypes, five female and two males, with same data as for holotype.

TyPE-LOCALITY. Spain, Tenerife island (Canary Islands), Cruz del Carmen.

Material DePosited. Museum of Zoology, Facultad de Ciencias, Universidad de Navarra (MZUNAV) (Spain).

MEASUREMENTS. Dorsal shield mean length 565 $\mu \mathrm{m}$; width at level of humeral processes (at level of seta $r 3) 315 \mu \mathrm{m}$.

DESCRIPTION (Figs. 1-9). Adult female (holotype). Gnathosoma: Tectum (Fig. 2) with three ramose projections, medial projection distally bend toward the right side. Deutosternum (Fig. 3) with five rows of denticles, first row behind the insertion of setae $h p 3$; hypostomal lacinea bifid, with internal branch longer than external branch. Corniculi long, similar in length to movable cheliceral digit, subequal to base of gnathosoma and 1.6 times the length of tibia I. Palp-trochanter (Fig. 7) with a thick distal seta in a small, rounded outgrowth. Cheliceral movable digits bidentate, as long as gnathosomal base (140 $\mu \mathrm{m})$ and 1.7 times the length of tibia I; basal tooth strigulate. Fifex digit with two distal and three basal teeth. Arthrodial membrane with weak corona and one brush; dorsal seta, pilis dentilus, dorsal lyrifissure and antiaxial lyrifissure normal.

Idiosoma dorsum (Fig. 1): Dorsal shield narrows toward the posterior end of the body in such a way that the shield, at level of humeral setae $r 3$, is nearly twice as wide as at level of setae S5. Shield with 30 pairs of thin, slightly pilose, dorsal setae: pair $j 1$ equal to $z 1(31 \mu \mathrm{m})$; setae $j 2$ are 1.4 times longer than $j 1$; humeral setae $r 2$ and $r 3(51 \mu \mathrm{m})$ are slightly longer than other central setae; 12 pairs of setae are on the soft cuticle: $r 6$ (less than a third the size of other podonotal setae), R1-R6, UR1-UR5; R1, R2, UR1 and UR2 are nearly twice as long as $r 6$. Dorsal and lateral adenotaxy and poroidotaxy as in Fig. 1 and include: on the podonotal shield idj1, idj4, idj5, idj6, $i d z 6$, ids2, ids4, gdj4, gdj6, gdzl and $g d s 4$; on the opisthonotal shield, idJ1, idJ2, idJ3, idJ4, idZ1, $i d S 1$, idS3, idS4, idS5 and $g d Z 2$; idR3 on the soft marginal cuticle.

Idiosoma venter (Fig. 4): Presternal shields are fragmented in seven pairs of coalescent platelets. Sternal shield wide, fused with endopodal shields, with anterior margin slightly concave and posterior margin rather straight; three pairs of 

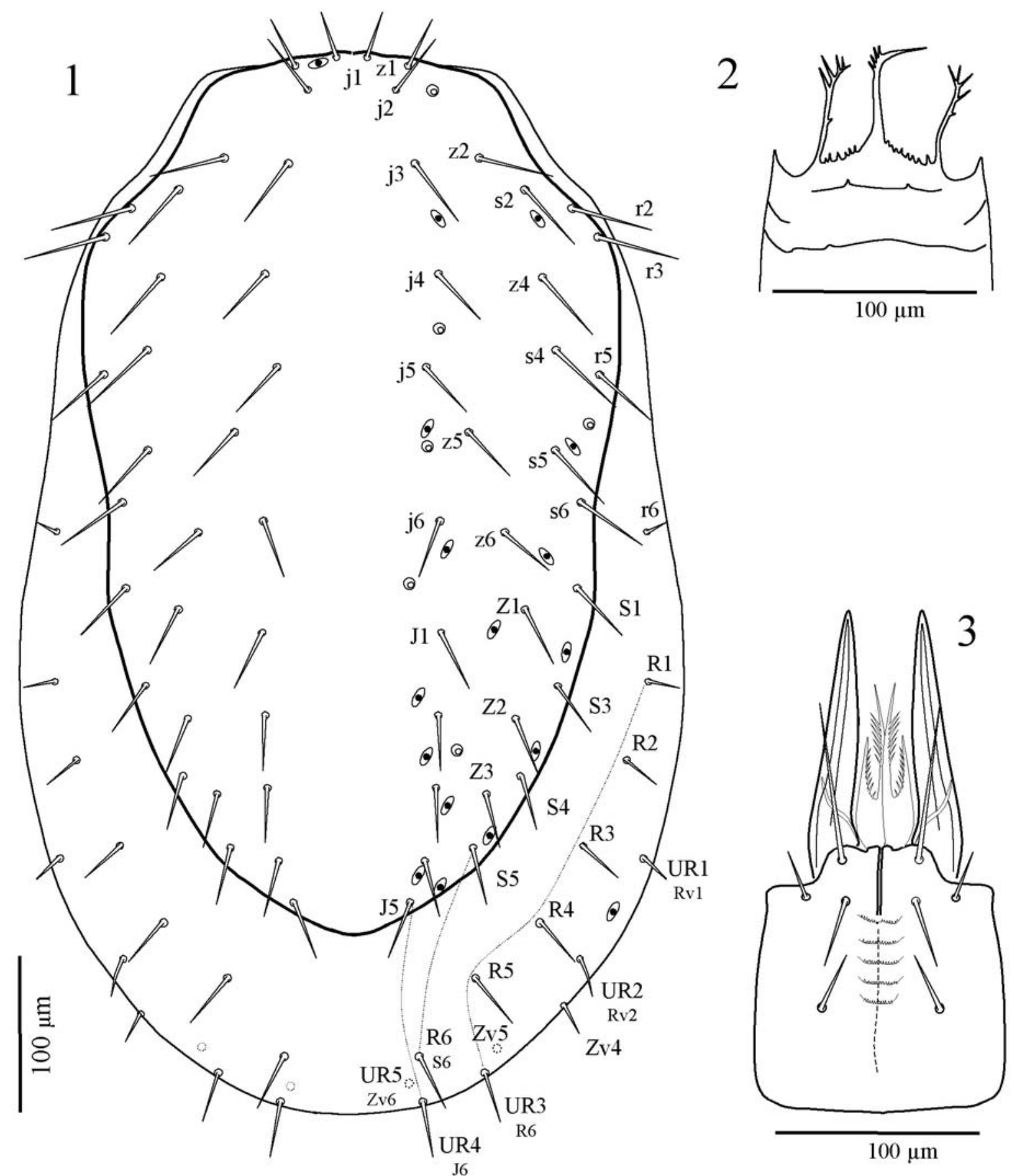

Figs. 1-3.- Holaspina canariensis, female: 1) idiosoma dorsal; 2) tectum; 3) subcapitulum.

Figs. 1-3.- Holaspina canariensis, hembra: 1) idiosoma dorsal; 2) tectum; 3) subcapitulum. 


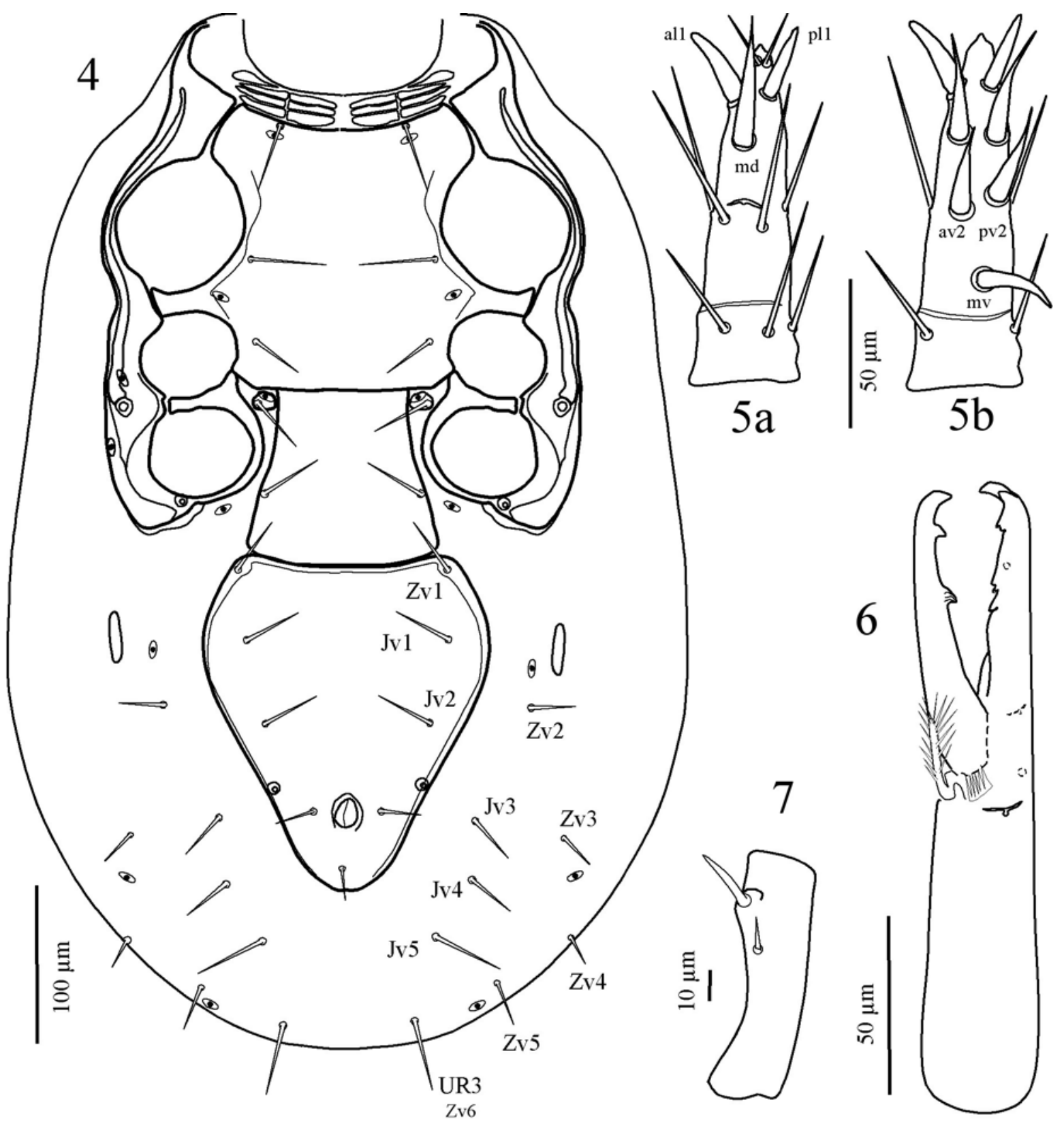

Figs. 4-7.- Holaspina canariensis, female: 4) Idiosoma ventral; 5a) Tarsus II, dorsal view; 5b) Tarsus II, ventral view; 6) chelicera; 7) Male, palp-trocanter, ventral view.

Figs. 4-7.- - Holaspina canariensis, hembra: 4) Idiosoma ventral; 5a) Tarsus II, vista dorsal; 5b) Tarsus II, vista ventral; 6) quelícero; 7) Macho, palpo-trocánter, vista ventral.

thin and smooth sternal setae and two pairs of lyrifissures (iv1 and iv2). Setae st4 on small metasternal shields together with iv4. Genital shield subtrapezoidal, with slightly convex poste- rior margin and nearly 1.5 times narrower than sternal shield, ratio length/width $<1(0.9)$; genital setae on the shield and similar to st4; iv5 off the shield. Ventrianal and genital shields coalescent; 


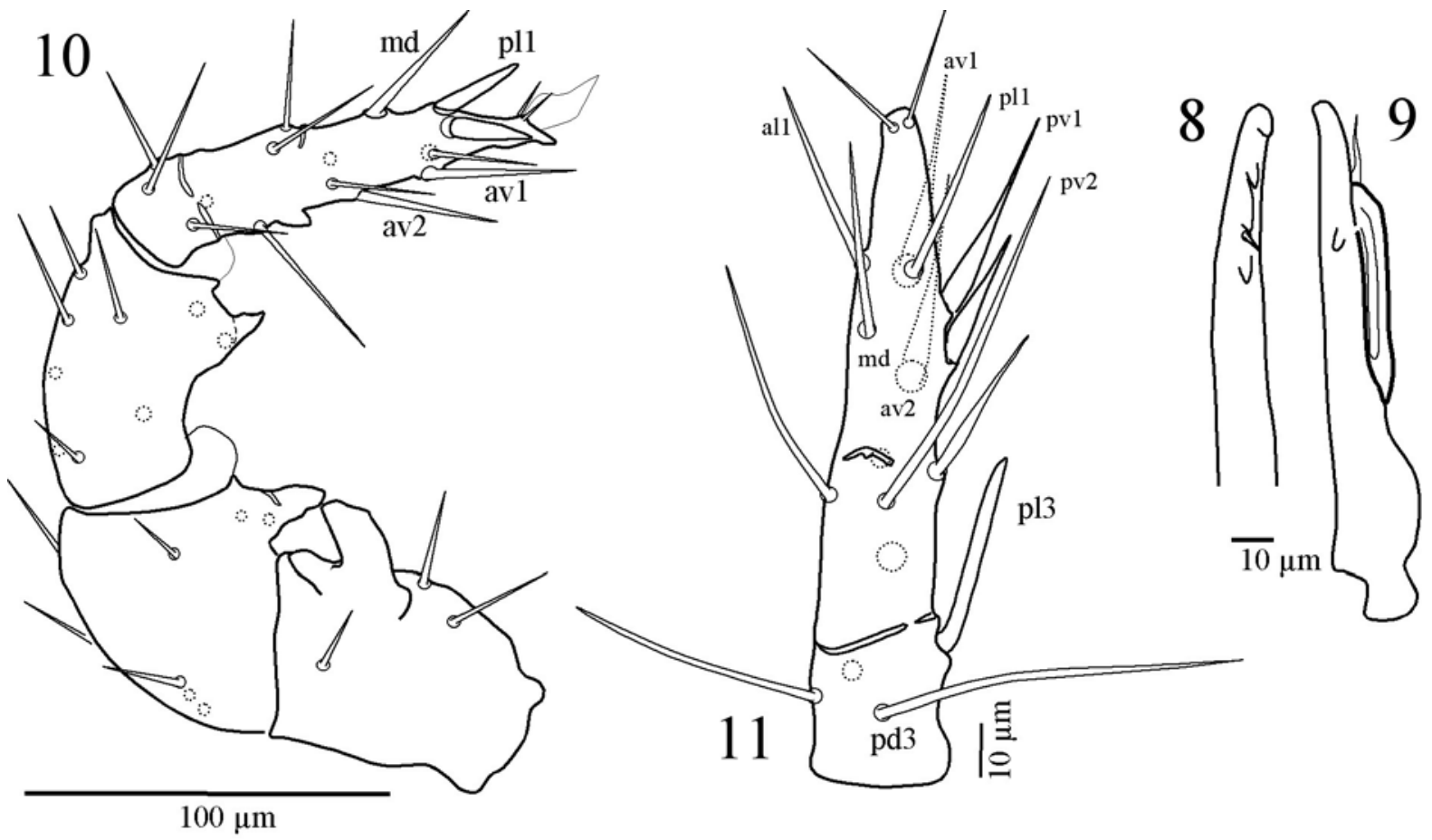

Fig. 8-11.- Holaspina canariensis, male: 8) detail of fixed cheliceral digit, ventral view; 9) movable cheliceral digit with spermatodactyl; 10) femora, genua, tibia and tarsus of leg II, anterolateral view; 11) leg IV, dorsal view.

Fig. 8-11.- Holaspina canariensis, macho: 8) detalle del dedo fijo del quelícero, vista ventral; 9) dedo móvil del quelícero con el espermatodáctilo; 10) fémur, genua, tibia y tarso de la pata II, vista anterolateral; 11) pata IV, vista dorsal.

ventrianal nearly twice as long and 1.5 times wider (at $J v 1$ insertion point) than genital shield, with three pairs of opisthogastric setae: $Z v 1$ on the anterolateral corners of the shield, $J v 1$ and $Z v 1$; setae $Z v 1$ length 3.5 times the distance between their bases; paranal setae are slightly shorter than other opisthogastric setae and longer than postanal seta; glands gv3 anterior to paranal setae. Seven pairs of opisthogastric setae and three pairs of lyrifissures in the soft cuticle; $J v 5$ are the longest setae, 1.3 times $R 4$.

Peritrematal shields fused with exopodals and extending behind posterior border of coxae IV. Peritreme do not reach posterior margin of coxae I. Small metapodal shields present.

Legs. Tarsus I without ambulacrum. Tarsus II (Figs. 5, 6) with one pair of spine-like distal setae (all and $p l l$ ) with a blunt end; setae $a v 1, p v 1, a v 2$, $p v 2$ and $m v$ are enlarge, spine-like setae, longer than setae "11" and with acute end. Tarsus IV with basitarsal $p d 3$ and telotarsal $p d 2$ macrosetae ( 74 $\mu \mathrm{m})$, basitarsal seta $p l 3$ thick, spatulate and blunt $(40 \mu \mathrm{m})$ and ventral setae spiny.

AdulT MALE. Measurements: Dorsal shield mean length $356 \mu \mathrm{m}$; width (at level of humeral processes, setae $r 3$ ) $172 \mu \mathrm{m}$.

Gnathosoma: Tectum similar to female. Spermatodactyl (Fig. 9) 0.5 times shorter than basal length of unidentate movable digit; dorsally bend, with acuminate apex and a short pilose excrescence (almost one-third the spermatodactyl length). Fixed digit tridentate (Fig. 8), with simple pilus dentilis.

Idiosoma. Dorsal shield similar to female although not so posteriorly acuminate. Twelve pairs of dorsal setae ( $r 6, R 1-R 6$ and UR1-UR5) and five pairs of opisthogastric setae on the soft cuticle $(J v 4$, $J v 5, Z v 3-Z v 5$ ). Holoventral shield with 10 pairs of setae in addition to three circumanal setae. Peritrematal shields similar to female. 
Table 1.- List of samples of Gamasholaspis gamasoides canariensis (type material not included).

Tabla 1.- Lista de muestras de Gamasholaspis gamasoides canariensis (no se incluye el material tipo).

\begin{tabular}{llccc}
\hline Code & Habitat & $\begin{array}{c}\text { Altitude } \\
\text { (m.a.s.l.) }\end{array}$ & $\begin{array}{c}\text { Coordinates } \\
\text { UTM }\end{array}$ & Locality \\
\hline T-39 & Mosses and hepatics on basaltic wall and logs & 750 & 28RCS 744 562 & Llano de los Viejos \\
T-40 & Soil and leaf litter & 750 & 25RCS 744 562 & Llano de los Viejos \\
T-47 & Lichens and mosses & 960 & 25.1997 & 25.I.1997 \\
T-48 & Soil and humus, with Senecio tussilaginis, & & & 25.I.1997 \\
& Gesnouinia arborea, Echium sp., Erica arborea, etc. & 850 & 28RCS 740 569 & Las Yedras \\
T-49 & Earth wall with lichens, mosses and Aeonium sp. & 850 & 28RCS 739 569 & Las Yedras \\
T-53 & Soil below E. arborea & 675 & 28RCS 823 586 & El Bailadero \\
T-56 & Soil and humus of Laurus azorica & 750 & 28RCS 845 592 & El Pijaral \\
T-59 & Cultivated soil decolonized by Canarina canariensis & 550 & 28RCS 867 606 & Chamorga \\
T-127 & Soil and humus below Phoeniculum vulgare & 630 & 28RCS 690 511 & 25.I.1997 \\
T-128 & Soil and humus below Cynodon dactylon & 630 & 28RCS 690 511 & 25.I.1997 \\
\hline
\end{tabular}

Legs. Coxae I with a small spin-like apophysis in the anteroventral margin. Tarsus I without ambulacrum. Tarsus II (Fig. 10) with two apical spinelike setae (all and $p l l)$, dorso medial seta $(m d)$ and three ventral setae (av1, pv1, av2) thicker than other setae of this segment and a small ventral apophysis in substitution of seta $m v$; genua and tibia II with a ventral spur; femur II with two ventral digitiform spurs, distal smaller than basal. Tarsus IV (Fig.11) as in the female.

ETYMOLOGY. The species epithet "canariensis" is a reference to the name of the Islands - the Canary Islands - where the mite was found.

Discussion. Holaspina canariensis belongs to the group of species without pretarsus I in both sexes, females with three pairs of opisthogastric setae on ventrianal shield, 30 pairs of dorsal setae and tarsus II with two spine-like latero-distal setae. Holaspina canariensis differs from $H$. alstoni (Evans, 1956) in the following characters: smaller body size of males in the new species (H. alstoni 480-500 $\mu \mathrm{m}$ ); in $H$. alstoni spermatodactyl is longer, 2/3-3/4 of the length of basal part of movable digit; adanal setae are similar in length to preanal setae and distal seta in palp-trochanter is not enlarged. In H. orientalis Petrova, 1967, movable cheliceral digit of the female is similar in length to or slightly longer than tibia I and the male has the holoventral shield with nine pairs of setae instead of ten. Holaspina pulchella Berlese, 1916 shows the tectum with medial projection longer than lateral and dorsal setae are longer in such a way that all them reach the insertion point of the following setae. Holaspina kamczaticus Petrova, 1977 has distal seta of palp-trochanter on a conspicuous digitiform protuberance in both sexes, 28 pairs of dorsal setae and small sclerites between genital and ventrianal shields.

Holaspina is found in Europe (Evans, 1956; Petrova, 1967, 1968, 1977), East and North America (Krantz, 1960) and Southeast Asia, in China (Lee \& Lee, 1996; Ma, 1998; Ma et al., 2001; Yin \& Bei, 1993), Japan (Ishikawa, 1980a, b) and Korea (Lee \& Lee, 2000).

\section{Gamasholaspis gamasoides canariensis subsp. nov.} (Figs. 12-19)

MATERIAL STUDIED. Holotype adult female (mounted, permanent slide), 25.I.1997, M.A. Peña leg., ex soil and wet litter from fayal - heath, altitude 950 m., UTM: 28RCS 756 572, (T46). Paratypes: 10 females and one male from the same locality and date.

OTHER MATERIAL (see Table 1): one female in T-39; one female in T-40; 2 females in T-47; one female in T-48; five in T-49; one male in T-53; three females, two males and one deutonymph in $\mathrm{T}-56$; one protonymph in T-59, eight in T-127 and one in T-128.

TYPE-LOCALITY. Spain, Tenerife Island (Canary Islands), Pico del Inglés.

Material DEPOSITED. Museum of Zoology, Facultad de Ciencias, Universidad de Navarra.

Measurements. Dorsal shield length $582 \mu \mathrm{m}$; width $315 \mu \mathrm{m}$.

DESCRIPTION (Figs. 12-19). Adult female (holotype). Gnathosoma (Figs. 13 y 14): Tectum (Fig. 13) with medial denticulate projection. Deutoster- 


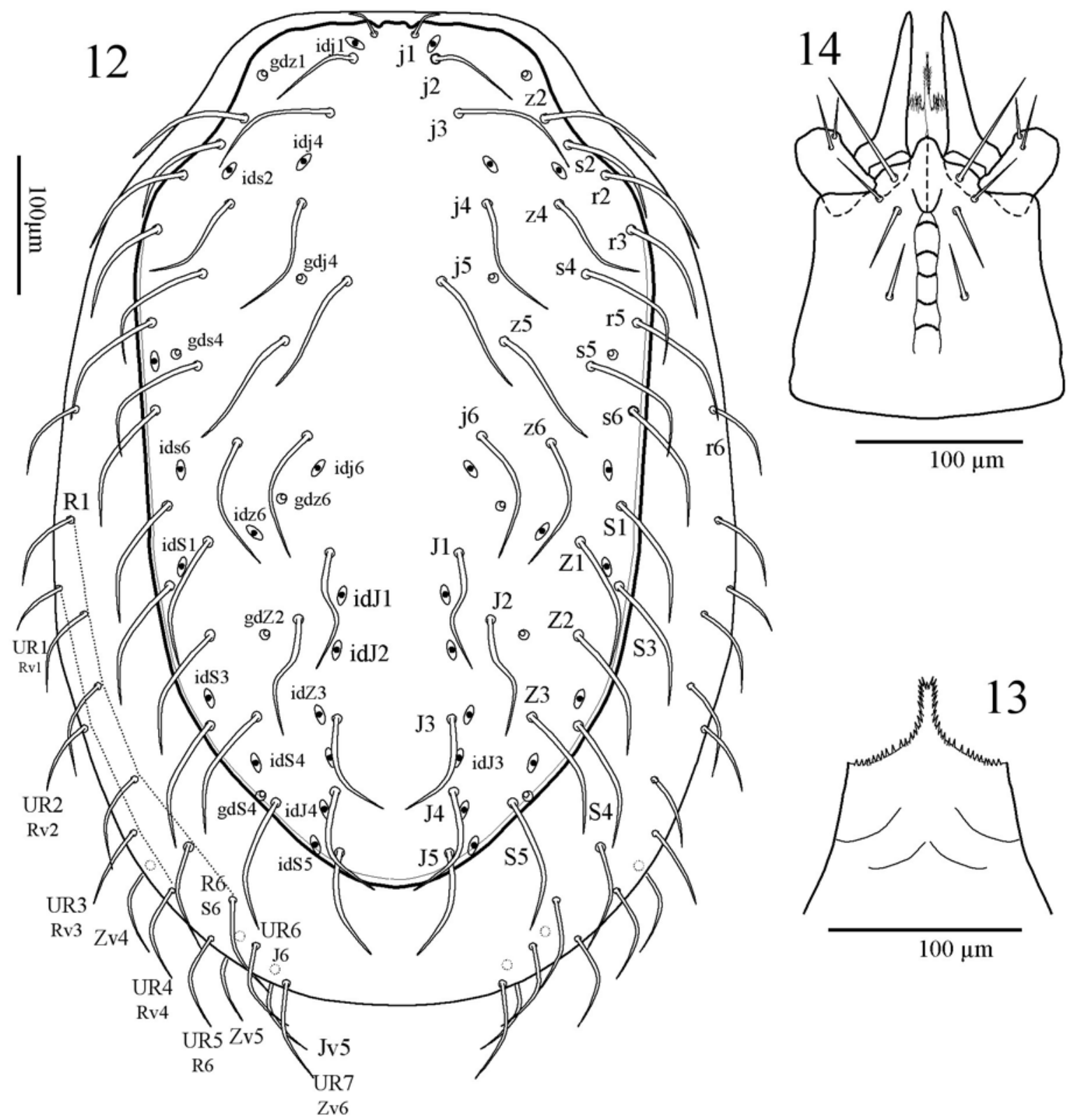

Fig. 12-14.- Gamasholaspis gamasoides canariensis, female: 12) idiosoma dorsal; 13) tectum; 14) subcapitulum.

Fig. 12-14.- Gamasholaspis gamasoides canariensis, hembra: 12) idiosoma dorsal; 13) tectum; 14) subcapitulum.

num with five rows of denticles, first row behind the insertion of $h p 3$; hypostomal lacinea with internal branch longer than external branch. Corniculi long $(145 \mu \mathrm{m})$, nearly 2.5 times longer than cheliceral movable digit, nearly half the gnathosoma base and 1.9 times tibia I. Cheliceral movable digit bidentate $(77 \mu \mathrm{m}), 0.4$ times the gnathosomal base and 0.8 times tibia I length; fixed digit with four teeth, the third tooth longer than the others and with pilus dentilis inserted at its base.

Idiosomal dorsum (Fig. 12): Dorsal shield with conspicuous humeral processes and posteriorly acuminate. Shield with 29 pairs of long, curved 

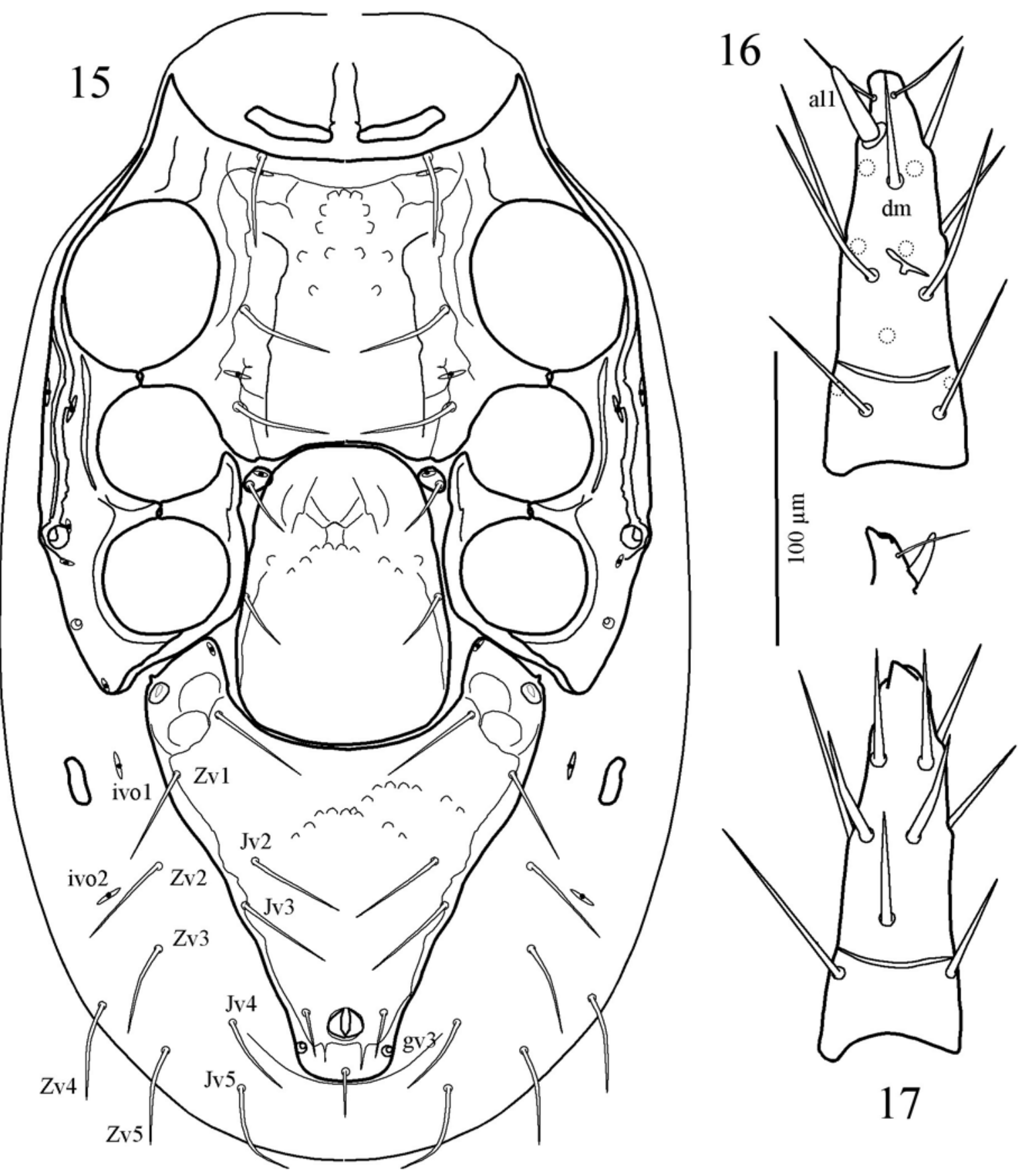

Figs. 15-17.- Gamasholaspis gamasoides canariensis, female: 15) idiosoma ventral; 16) tarsus II, dorsal view; 17) tarsus II, ventral view.

Figs. 15-17.- Gamasholaspis gamasoides canariensis, hembra: 15) idiosoma ventral; 16) tarsus II, vista dorsal; 17) tarsus II, vista ventral. 

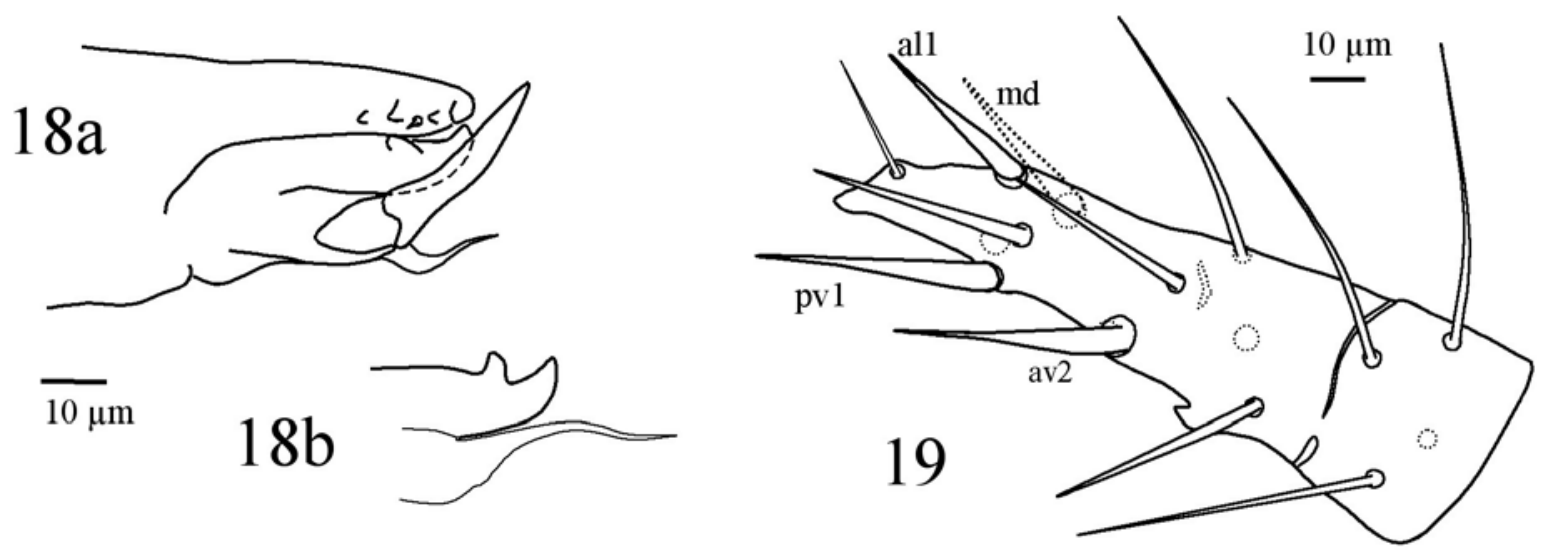

Figs. 18-19.- Gamasholaspis gamasoides canariensis, male: 18a) chelicera and spermatodactyl, ventral view; 18b) detail of the spermatodactyl pilose excrescence; 19) tarsus II, anterolateral view.

Figs. 18-19.- - Gamasholaspis gamasoides canariensis, macho: 18a) quelícero y espermatodáctilo; 18b) detalle de la excrecencia pilosa del espermatodáctilo; 19) tarsus II, vista anterolateral.

setae $(92 \mu \mathrm{m})$, except $j 1(19 \mu \mathrm{m})$ which is almost three times shorter than $j 2(60 \mu \mathrm{m})$. Fourteen pairs of setae are on the marginal soft cuticle $(r 6, R 1-R 6$ and UR1-UR7): r6, R1-R4, UR1-UR4 approximately half the size of setae on dorsal shield. Dorsal idiosomal pore-like structures positioned as in Fig. 12 and include: on the podonotal shield six pairs of lyrifissures (idj1,idj4, idj6, idz6, ids2, ids4) and four pairs of glands ( $g d j 4, g d z 6, g d z 1$ and $g d s 4)$; on the opisthonotal shield, nine pairs of lyrifissures (idJ1, idJ2, idJ3, idJ4, idZ3, idS1,idS3, idS4, idS5) and two pairs of glands ( $g d Z 2, g d S 4)$; idR3 on the marginal soft cuticle.

Idiosomal venter (Fig. 15): One pair of presternal elongate shields. Sternal shield fused with endopodal shields I and II, with nearly linear anterior margin and slightly convex posterior margin. Sternal setae smooth, similar in length to other ventral setae $(58 \mu \mathrm{m})$. Small and rounded sternal shields with st4 $(35 \mu \mathrm{m})$ and lyrifissures $i v 4$. Genital shield with anterior rounded margin and genital setae 0.7 times shorter than sternal setae $s t 1$ st 3 and similar to st 4 ; ratio length/width 1.4. Anterior margin of ventrianal shield with a deep notch in which is positioned the posterior part of the genital shield; maximum width 3.7 times wider than minimum width at level of postanal seta; shield has a pair of conspicuous glands ("posterostigmal organ") $g v 2$ in the anterolateral corners associate with an ornate area and genital lyrifissures $i v 5$; four pair of opisthogastric setae (Jv1-Jv3 and
Zv1) similar to sternal setae on the ventrianal shield; paranal setae shorter; glands gv3 posterior to paranal setae. Six pairs of opisthogastric setae on the soft ventral cuticle $(J v 4, J v 5, Z v 2-Z v 5)$. Small metapodal shields. Peritrematal shields fused with exopodals, except for a short gap between coxae I and II and between posterior border of coxae II and posterior border of coxae III; shields extend behind coxae IV, reaching the position of glands gv2; porelike structures positioned as in Fig. 15. Peritreme almost reaches the insertion of setae $j 2$.

Legs. Tarsus I without pretarsus. Tarsus II (Figs. $16,17)$ with acuminate distal end, one spine-like apical seta (all), seta $d m$ and ventral setae slightly enlarge and shorter than other dorsal tarsal setae.

Adult male. Measurements: Dorsal shield mean length $445 \mu \mathrm{m}$; mean width $258 \mu \mathrm{m}$.

Gnathosoma: Tectum similar to female. Spermatodactyl (Fig. 18a) similar in length to basal part of unidentate movable cheliceral digit (the base in considered as the anterior initial point of the spermatodactyl). Pilose excrescence at the base, as long as the spermatodactyl (Fig. 18b). Fixed digit tridentate.

Idiosoma. Dorsal shield similar to female with 11 pairs of dorsal setae on the soft cuticle $(r 6, R 1$ $R 6$, four setae $U R$ ). Four pairs of opisthogastric setae on holoventral shield ( $J v 1-J v 3, Z v 2, Z v 1$ absent) and five pairs on the soft cuticle $(J v 4, J v 5$, Zv3-Zv5). 
Legs. Tarsus I without pretarsus. Tarsus II (Fig. 19) with setae $a l 1, d m, p v 1$ and $a v 2$ slightly enlarge, no spine-like setae; a small spine-like ventral apophysis. Tibia II with a large ventral digitiform spur; genua and femur II with poor developed ventral spur.

ETYMOLOGY. The subspecies name "canariensis" refers to the Canary Islands, where the species was collected.

Discussion. Although idiosomal characteristics of this taxa resemble G. gamasoides Berlese, 1904 , absence of pretarsus I in both sexes, in addition to the absence of spine-like seta in tarsus II of the male and relative length of setae $j 1$, provide sufficient reason to considered the Canarian specimens as members of a new subspecies. Other species lacking pretarsus I and $j 1$ less than half the length of $j 2$, such as G. incisus Petrova, 1968, do not have the ventrianal notch and tectum has three points.

The genus Gamasholaspis has been reported in Russia, Italy and Argentina (Petrova, 1977), China (Gu, 1984; Lian et al., 1993; Gu \& Guo, 1996; Chen et al., 1994; Ma \& Yin, 1999), Korea (Lee \& Lee, 1996), Thailand (Ishikawa \& Saichuae, 1997), Japan (Ishikawa, 1995, 1980 b) and India (Roy, 1994).

\section{General discussion}

Concerning the idiosomal chaetotaxy, Lindquist (1994) did not recommend changing the notation for setal seri $U R$ to $R V$, as the siglum UR is well established and widely used. However, he did recommend its recognition and the denotation of ventral setae $Z v 4$ and $Z v 5$ because of their systematic importance. For $R 6$ and the other $U R$ setae, he indicated that for $R 6$ and others $U R$ setae it was probably impossible to precisely resolve which may represent the sixth elements of the dorsal or ventral series of setae. Based on positions of caudal setae present in the two taxa here described, and considering that the caudal bend discussed by (Lindquist, 1984) is retained, a tentative recognition of these caudal setae has been made, as can be see in figures 1,4 , 12 and 15 .

In Holaspina and Gamasholaspis, dorsal series $J, S$ and $R$ and ventral series $J$ and $Z$ may be complete and as Lindquist (1994) suggested, Jv6 may represent the proctal paraanal setae. This pattern is consistent with other Parholaspid genera.

\section{References}

Chen, W., Guo, X. \& Gui, Y., 1994. A new species of Gamasholaspis from China (Acari: Parholaspidae). Acta Arachnologica Sinica, 3(1): 61-64.

Datta, A. K. \& Bhattacharjee, P. C., 1989. Krantzolaspina rebatii, a new genus and a new species (Acari: Mesostigmata: Parholaspidae) from Dibrugarh, Assam, India. In: G. P. Channabasavanna \& C. A. Viraktamath (eds.) Progress in Acarology, vol. 1. Oxford \& IBH Publishing Co. New Delhi: 411-414.

DattA, A. K. \& BhattacharjeE, P. C., 1991. Hyattolaspina hiteni, a new genus and a new species of the family Parholaspidae (Acari, Mesostigmata) from Jorhat, India. In: G. K. Veeresh, D. Rajagopal \& C. A. Viraktamath (eds.) Advances in management and conservation of soil fauna. Oxford \& IBH Publishing Co. New Delhi: 717-720.

Domingo-Quero, M. A., Alonso-Zarazaga, M. A., Sánchez-Ruiz, A., Araujo Armero, R., Navas SÁnchez Ruiz, M., Fontal-Cazalla F. \& NievesAlDREY, J. L., 2003. Inventariando la biodiversidad en el Parque Nacional de la Caldera de Tabueriente (La Palma, Islas Canarias, España): Novedades científicas. Graellsia, 59(2-3): 45-68.

Estrada-PeÑA, A. \& SÁnchez, C., 1988. Two new species of Steatonyssus (Acari, Macronyssidae) from bats of the Canary Islands, with the description of male and protonymph of Parasteatonyssus hoogstraal (Keegan). Revista Ibérica de Parasitología, 48(3): 303-311.

EvANS, G. O., 1956. On the classification of the family Macrochelidae with particular reference to the subfamily Parholaspinae (Acarina - Mesostigmata). Proceedings of the Zoological Society of London, 127: 345-377.

Evans G. O., 1963. Observations on the chaetotaxy of the legs in the free-living Gamasina (Acari: Mesostigmata). Bulletin of the British Museum (Natural History). Zoology, 10: 277-303.

Ferragut, F. \& Peña-Estévez, M. A., 2003. Phytoseiid mites of the Canary Islands (Acari: Phytoseiidae): 1. Gran Canaria Island. International Journal of Acarology, 29(2): 149-167.

Gu, Y., 1984. A new species of the genus Gamasholaspis from China (Acarina: Parholaspidae). Acta Zootaxonomica Sinica, 9(4): 375-377.

Gu, Y. \& GuO, X., 1996. A new species of Gamasholaspis from China (Acari: Parholaspidae). Acta Zootaxonomica Sinica, 21(3): 309-311.

IsHIKAWA, K., 1978. The family Parholaspidae (Acarina, Mesostigmata) in Japan. ITE-Symposium, 20: 91-93.

IsHIKAWA, K., 1980a. Taxonomic and ecological studies in the family Parholaspidae (Acari, Mesostigmata) 
from Japan. Bulletin of the National Science Museum Series A (Zoology), 6(1): 1-25.

IsHIKAWA, K., 1980b. Taxonomic and ecological studies in the family Parholaspidae (Acari, Mesostigmata) from Japan (Part 3). Bulletin of the National Science Museum Series A (Zoology), 6(3): 153-174.

IsHIKAWA, K., 1995. A new Gamasholapis (Acari, Gamasida, Parholaspidae) collected from a natural cave of Japan. Bulletin of the Japanese Society of Coleopterology, 4: 111-114.

IsHIKAWA, K., 2002. A new species of the genus Parholaspulus (Acarina: Gamasina, Parholaspidae) from a cave of southwest Japan. Journal of the Speleological Society of Japan, 27: 27-31.

IshiKawa, K. \& Saichuae, P., 1997. Two new gamasid mites (Acari, Gamasida, Podocinidae and Parholaspidae) from the tropical rain forests of Khao Yai Province in Thailand. Journal of the Acarological Society of Japan, 6(1): 65-71.

Johnston, D. E. \& MorazA, M. L., 1991. The idiosomal adenotaxy and poroidotaxy of Zerconidae (Mesostigmata: Zerconina). In: F. Dusbábek \& V. Bukva (eds.). Modern acarology. Vol. II: Proceedings of the 8 International Congress of Acarology held in Ceske Budejovice, Czechoslovakia, 6-11 August 1990. Academia Prague and SPB Academic Publishing. The Hague: $349-356$.

Krantz, G.W., 1960. A reevaluation of the Parholaspinae Evans, 1956 (Mesostigmata: Macrochelidae). Acarologia, 2(4): 393-433.

LEE, S. Y. \& LEE, W. K., 1996. Three soil mites of the family Parholaspidae and Podocinidae (Mesostigmata, Acari) from Korea. Korean Arachnology, 12(2): 131137.

LeE, S. Y. \& LeE, W. K., 2000. Taxonomic study of Parholaspid mites (Acari, Mesostigmata) in Korea. Korean Journal of Systematic Zoology, 16(1): 105112.

LiAnG, L. R. \& Hu, C., 1993. A new species and a new record of the genus Praholaspina ishikawa from China (Acari, Mesostigmata: Parholaspidae). Acta Zootaxonomica Sinica, 18(1): 63-65.

LindQuist, E. E., 1984. 1. Speciation \& evolution in Acari 1.3 Current theories on the evolution of major groups of Acari and on their relationships with other Arachnida, with consequent implications for their classification. In: D. A. Griffiths \& C. E. Bowman (eds.). Proceedings of the $6^{\text {th }}$ International Congress of Acarology, Edinburgh, Sep. 1982. Acarology, 6(1): 28-62.

LINDQUIST, E. E., 1994. Some observation on the chaetotaxy of the caudal body region of gamasine mites (Acari: Mesostigmata), with a modified notation for some ventrolateral body setae. Acarologia, 35(4): 323-326.
LindQuist, E. E. \& Evans, G. O., 1965. Taxonomic concepts in the Ascidae, with a modified setal nomenclature for the idiosoma of the Gamasina (Acarina: Mesostigmata. Memoirs of the Entomological Society of Canada, 47: 1-64.

LindQuist, E. E. \& MoraZA, M. L., 1999. Observations on homologies of idiosomal setae in Zerconidae (Acari: Mesostigmata), with modified notation for some posterior body setae. Acarología, [1998], 39: 203-226.

MA, L., 1998. Two new species of the genus Parholaspulus (Acari: Gamasina: Parholaspidae). Acta Arachnologica Sinica, 7(2): 81-85.

MA, L. \& YIN, X., 1999. Two new species of the family Parholaspidae (Acari: Gamasina). Entomotaxonomia, 21(1): 74-78.

MA, L., Yin, X. \& Chen, P., 2001. Description on deutonymph of Parholaspulus paradichaetes and protonymph of Parholaspulus bregetovae (Acari: Gamasina: Parholaspidae). Entomological Journal of East China, 10(2): 117-119.

MACHADO, A., 2002. La biodiversidad de las islas Canarias. In: E. D. Pineda, J. M. de Miguel, M. A. Casado \& J. Montalvo (eds.-coords.). La diversidad biológica de España. Prentice Hall. Madrid: 89-99.

Moraza M. L. \& PeÑA, M. A., 2005a. Ácaros Mesostigmata (Acari: Mesostigmata) en hábitats seleccionados de la isla de Tenerife (islas Canarias). Graellsia, 61(1): 109-114.

Moraza M. L. \& PeÑA M. A., 2005b. The family Pachylaelapidae Vitzthum, 1931 on Tenerife Island (Canary Islands), with description of seven new species of the genus Pachylaelaps (Acari, Mesostigmata: Pachylaelapidae). Acarologia, [2004], 55(2-3): 103-129.

Moraza M. L., PeÑa, M. A. \& Ferragut, F. J., 2005. Two new species of Neoseiulella Muma of the Canary Islands (Acari: Phytoseiidae). International Journal of Acarology, 31(2): 107-112.

Oromí, P. \& BÁEz, M., 2001. Phylum Arthropoda. In: I. Izquierdo, J. L. Martín, N. Zurita \& M. Arechavaleta (eds.). Lista de especies silvestres de Canarias (hongos, plantas y animales terrestres). Consejería de Política Territorial y Medio Ambiente. Gobierno de Canarias: $149-427$.

Petrova, A. D., 1967. Mites of the family Parholaspidae Krantz, 1960 (Parasitiformes, Gamasoidea) from the Soviet Unio. Bulletin de la Société des Naturalistes de Moscou. Section Biologique, 72(2): 38-55.

Petrova, A. D., 1968. Gamasoid mites of the genus Holaspina (Gamasoidea, Parholaspidae) of the fauna of the USSR. Entomological Review, 47(3): 656-670.

Petrova, A. D., 1970. [Mites of the family Parholaspidae in the USSR, a new elements of the ManchurioChinese fauna (Parasitiformes, Gamasoidea).] In: [Oribatid (Oribatei) and their role in soil-forming 
processes.] Zoologijos ir Parazitologijos Institutas (Lietuvos TSR Mokslu Akademija). Vilnius: 45-54 (en ruso).

Petrova, A. D., 1977. [Family Parholaspidae.] In: M. S. Ghilarov and N. G. Bregetova (eds.). [Handbook for the identification of soil inhabiting mites. Mesostigmata.] Nauka. Leningrad: 315-346 (en ruso).

Roy, R. K., 1994. A note on Parholaspidae Krantz, 1960 with supplementary data for Gamasholaspis browningi (Bregetova \& Koroleva, 1960) from India. Journal of the Bombay Natural History Society, 91(1): 154-155.
Yin, S. \& BeI, N., 1993. Two new species and four new records of the genus Parholaspulus from China (Acari: Parholaspidae). Acta Zootaxonomica Sinica, 18(4): 434-437.
Recibido, 2-III-2006

Aceptado, 31-V-2006 Publicado, 30-VI-2006 